\title{
Alterity and Repetition. Phenomenological Interpretation OF the Divinity in the Later Heidegger
}

\author{
ALTERIDAD Y REPITICIÓN. INTERPRETACIÓN \\ FENOMENOLógica de LA DIVINIDAD EN EL HEIDEgGer taRdío
}

\begin{abstract}
The purpose of this paper is phenomenological interpretation of the various faces of divinity in the later Heidegger and elucidation of the human comportment corresponding to this divinity. In the first chapter, I will make clear the relation between ontological difference in the sense of the later Heidegger and the primordial dimension of divinity which is called the last god (der letzte Gott) and the sacred (das Heilige). Further, the relation between such divinity and entity as a whole (das Seiende im Ganzen) will be clarified. In the second chapter, I will elucidate the place of the divinities in the manifestation of entity as a whole by considering the role of the godlikes (die Göttlichen) in the fourfold (das Geviert). When the primordial alterity of the last god should be experienced in entity as whole, which leads to the notion of the godlikes, it must confront human subject in totally asymmetrical manner. Such asymmetrical communication can be structurally made explicit by taking the concept of "discourse" in Being and Time into account. Finally, I will consider the character of human comportment called preservation (Bergung) with focusing on its relation to the later Heidegger's conceptions of divinity. This will shed light on how human beings could properly appreciate the experience of what is beyond our understanding and nevertheless supporting our existence.
\end{abstract}

Key Words: Heidegger, Last God, Sacred, Religiosity, Alterity, Phenomenology, Existential Thought.
Resumen: El objetivo de la ponencia es llevar a cabo una interpretación fenomenológica de las diversas facetas de la divinidad en el Heidegger tardío y elucidar el comportamiento humano respecto de esta divinidad. En el primer capítulo, se esclarece la relación entre la diferencia ontológica en el sentido que le da el segundo Heidegger y la dimensión primordial de la divinidad, llamada el último dios (der letzte Gott) y lo sagrado (das Heilige). A continuación, se esclarecerá la relación entre la divinidad así concebida y lo ente en totalidad (das Seiende im Ganzen). En el segundo apartado, se elucidará el lugar de las divinidades en la manifestación de lo ente en totalidad considerando el papel de los divinos la Cuaternidad (das Geviert). Cuando la alteridad primordial del último dios se experimente en lo ente en totalidad, lo cual conduce a la noción de los divinos, tiene que enfrentarse al sujeto humano de una forma totalmente asimétrica. Esta comunicación asimétrica puede explicitarse estructuralmente mediante la consideración del concepto del discurso en Ser y tiempo. Finalmente, consideraré el carácter del comportamiento humano denominado la preservación (Bergung), con especial atención a su relación con la noción de lo divino en Heidegger tardío. Esto arrojará luz sobre cómo los seres humanos podrían apreciar de manera adecuada lo que está más allá de nuestra comprensión y sin embargo, sostiene nuestra existencia.

Palabras clave: Heidegger, el último dios, lo sagrado, religiosidad, alteridad, fenomenología, pensamiento existencial. 


\section{INTRODUCTION}

We sense the experiences that emerge for us in radically asymmetric ways, experiences which call for our response, such as the experience of the divinity in positive religions, or at least call for contact with a pious individual or religious monument like a church or temple. Such human response plays an important role in our life, for example, in devoting prayer for the divinity or showing respect for the faith of others. Then, what is the essence of this experience? Further, what is it like to properly respond to this experience? In this paper, we will try to answer to this question by suggesting a phenomenological interpretation of the divinity and the human response to it in the later Heidegger.

As was suggested by von Herrmann, Heidegger's conceptions of the divinity must be categorized into different dimensions ${ }^{1}$. However, to the best of my knowledge, there seems to be no inquiry giving phenomenological justification of Heidegger's description, but rather such interpretations where this divinity is simply defined as the antithesis of ontotheology and is not itself further examined $^{2}$, or purely historical investigations trying to clarify Heidegger's relationship to Hölderlin or Christian mysticism ${ }^{3}$. Due to such research limitations, the philosophical relevance of Heidegger's descriptions has not yet been sufficiently ar-

\footnotetext{
${ }^{1}$ von Herrmann, Friedrich-Wilhelm, "Die Gottesfrage im seinsgeschichtlichen Denken", in Pöltner, Günter (hrsg.), Auf der Spur des Heiligen, Böhlau, Wien, 1991, pp.23-39, p.35f., also p.38. However, singe von Herrmann provides no explicit explanation for the reason why the divinity by Heidegger is involved in the twofold of Being, his commentary remains philosophically insufficient.

2 Thurner, Rainer, "Gott und Ereignis: Heideggers Gegenparadigma zur Onto-Theologie", in: Heidegger Studies, Vol.8, Berlin, 1992, S.81-102; Thurner emphasizes the role of mood in Heidegger's conceptions of divinity as the anti-thesis against metaphysical theology (p.96ff.). Though this could be justified to certain extent, it doesn't explain the significance of "the call (Nennen)" of the god by Heidegger. Further, Thurner provides no explanation for why the divinity should arrive in mood.

${ }^{3}$ As the early commentary for the divinity in the later Heidegger, see, Pöggeler, Otto, Der Denkweg Maritin Heideggers, Neske, Pfullingen, 1963, p.261; Recently, Pöggeler published detailed historical research on the relation between Heidegger and Marburg Theology. See, Pöggeler, Otto, Philosophie und hermeneutische Theologie. Heidegger, Bultmann und die Folgen. Wilhelm Fink, Paderborn 2009: As a research on the relation with Hölderlin, see, Trawny, Peter, "Der kommende und der letzte Gott bei Hölderlin und Heidegger", in Trawny, Peter (hrsg.), Vollverdienst doch dichterisch wohnet der Mensch auf dieser Erde, Klostermann, Frankfurt a.M., 2000, S.199-220; Trawny gives detailed elucidation about the relation between Heidegger's conceptions of the divinity and Hölderlin's poetry like « Brot und Wein », which itself is very relevant but doesn't answer the question why the phenomenon involves something like the sacred. As a research on the relation with mysticism, see, Helting, Holger, "Heidegger und Meister Eckehart", in Coriando, Paola-Ludovia (hrsg.), Herkunft aber bleibt stets Zukunft, Klostermann, 1998, S.83-10; However, this excellent paper also shifts its focus to Heidegger's interpretation of Trakl just in the moment it tries to clarify how the sacred is thought from the truth of Being (p.89f.), which makes it philosophically insufficient. Recently, Schüssler published very detailed and comprehensive study on this field; Schüssler, Ingeborg, "Le "dernier dieu" et le délaissement de l'être ", in Heidegger Studies, vol.25 (S.49-78), 2009, Vol.26(S.125-163), 2010: Further, Esposito took a little similar approach with us in that he elucidates "Vorbeigang" by referring to "Geschehen" in Being and Time; Esposito, Constantino, "Die Geschichte des letzten Gottes", in Heidegger Studies, vol.11, 1995
} 
ticulated. In the following, we will try to comment and reconstruct these varieties of the divinity in the later Heidegger by considering their relationship to the fundamental framework in the early and later philosophy of Heidegger.

Three points will be thereby of the greatest importance. The first is the position of the divinity in the most important philosophical insight of the later Heidegger, namely, the twofoldness of "the clearance (Lichtung)" and "the concealment (Verbergung)". The second is the position of the divinity in "the entity as a whole (das Seiende im Ganzen)", which involves us as Dasein. The third is the specific determination of human response to the divinity in the thinking of Being in general. As we will see in the following, the first point is related to "the last god (der letzte Gott)" and "the sacred (das Heilige)" (Chap. 1), the second to "the godlikes (die Göttlichen)" and "the gods (Götter)" (Chap. 2), and the third to the specific definition of "sacrifice (Opfer)" within "the preservation (Bergung)" of the truth of Being in general (Chap. 3). In the following, we will consider these three problems and maintain that "the last god" and "the sacred" are involved in the concrete experience of the twofoldness of "the clearance" and "the concealment", that "the godlikes" signify the aspect of entity in this experience of radical alterity, and that "sacrifice" realizes one possible manner of the thinking of Being by leaving and entrusting the entities possessed by us to this alterity.

\section{Event and Alterity: "The Sacred" and "The Last God"}

As was stated above, there are various terminologies about divinity in the later Heidegger. Among them, "the sacred (das Heilige)" and "the last god (der letzte Gott)" should first be investigated ${ }^{4}$, because Heidegger regards them to be firmly correlated with, or even equivalent to, the twofoldness of "the clearance" and "the concealment". In Contributions to Philosophy (1936-38: in the following, $C P$ ) the following was stated:

Rejection (of Being) is the highest dignity of the donation (of Being) and the fundamental disposition of the self-concealment. This openness of the self-

\footnotetext{
${ }^{4}$ As the commentary on "the sacred" and Hölderlin, See, Fédier, François, "Die Spur des Heiligen", in Pöltner, Günter (hrsg.), Auf der Spur des Heiligen, Böhlau, Wien, 1991, S.40-48, S.43
} 
concealment is the primal essence of the truth of the Being. Only in this way, the Being becomes the alterity itself (Befremdung), namely, the silence of the distant advent of the last god (GA65, p.406, my emphasis). ${ }^{5}$

Simply put, the point here is that a sense of alterity (Befremdung) is regarded as united with the clearance and the concealment of Being. Moreover, the passage from On the Beginning (1940) shows that this alterity must be distinguished from "the Gods", that is, the divinity Heidegger describes in plural ${ }^{6}$.

About such statements, (1) we must first clarify why and in what sense the alterity is involved in the twofoldness of the clearance and the concealment, (2) and second elucidate the relationship between this alterity and the entities, that is, the entities which are thus called, insofar as they come into existence in the clearance and the concealment.

(1) To begin, I would like to presuppose that the twofoldness above should be paraphrased as the fundamental character of becoming of phenomenon in general, namely, as the character of emergence in which the entities come into existence in each moment. The reason such emergence needs to be characterized as the clearance and the concealment can be explained by contrasting it against "authentic disclosure (eigentliche Erschlossenheit)" in Being and Time (1927: in the following, BT) and the thought of "transcendence" in the metaphysical period from the late 1920 s to the early 1930s. As is well known, in BT, the comportment in the world and the appearance of the entities are regarded possible only on the ground of authentic temporalization of singular Dasein. In other words, becoming of phenomenon is here sought in becoming of the selfhood of Dasein, which is strictly distinguished from other entities in the world such as tools, physical objects or other people. However, in the later metaphysical writings such as the Leibniz-lecture, the nuance in the account of phenomenalisation is modified, since Heidegger here assumes "the nature" or "the entity as a whole (das Seiende im Ganzen)" which should be even presup-

\footnotetext{
${ }^{5}$ See also the following passages: "The inner finitude of Being (Seyn) is disclosed here, namely in the wink of the last god" (GA65, p.410). "The last god is not the end, but the self-formation (Insicheinschwingen) of the beginning, and thus the highest form of the rejection (of Being), because the beginning retreat from every stabilization, and as the advent, is caught in the last god and handed down to his decisive power." (GA65, p.416 my supplement). About "the sacred", see the following passage from On the Beginning (1940): "Both (the sacred and Being) could be both equated and distinguished. The accordance of these names is in that they indicate the eventual happening of their reigning <saving > before the gods and human beings. [...] The sacred and Being is [...] the name of the other beginning (der andere Anfang)." (GA70, p.157, my supplement in (), <> by Heidegger)

6 See note 5
} 
posed by "factic existence of Dasein" (See, GA26, p.199). That is, the origin of phenomenalisation is here shifted to "the entity as a whole" preceding and involving Dasein, while Dasein is supposed to afterwards transcend the entities and disclose the essential structure of their emergence. However, such theoretical modification needs further reconsideration, because it is impossible to presuppose "the entity as a whole" as what Dasein could transcend. It is also impossible to presuppose that "the entity as a whole" reveals the essence of its emergence, if it should ontologically precede Dasein itself. Such presupposition would be possible only on the ground of phenomenologically unreasonable assumption of the speculative unity between "the entity as a whole" and Dasein". Therefore, to properly describe the origin of phenomenalisation, it is necessary to give up the thought of "transcendence" which demands "the move from the entity to its being", as was stated in CP (GA65, p.322). Rather, what is demanded is to observe the emergence of "the entity as a whole" from the standpoint inside the entity (not of transcendence) and to "preserve (Bergung)" this truth inside the entity (GA65, p.322). Now, if we should intrinsically consider phenomenalisation, it is clear that an essential two-sidedness be attributed to it. On one hand, since the emergence of "the entity as a whole" happens in the manner that Dasein always gets involved there, phenomenalisation is the most actual given one could contemplate. On the other hand, as the subject matter here is each emergence in which this thinking Dasein is being involved, it is impossible for Dasein to grasp phenomenalisation in the manner that phenomenalisation be inquired as a condition of possibility of the entity, which

\footnotetext{
${ }^{7}$ However, as long as the possible theoretical implication of Heidegger's metaphysics remains inexplicit, we cannot understand the relevance of the later writings after $C P$. In my opinion, the essence of Heidegger's metaphysical period is in the expression "the being of the entity as such as a whole (das Sein des Seienden als solchen im Ganzen)". In On the Essence of the Language (after the late 30's), it is stated that this has been the final object of his earlier investigation untill 1931, namely, of the task of repeating traditional metaphysics on the new foundation (GA74, p.8). This expression consists of the two components, namely, "the entity as such (das Seiende als solches)" and "the entity as a whole (das Seiende im Ganzen)". According to the lecture in SS1928, the former corresponds to the object of funadamental ontology as the study of the understanding of Being in general (GA26, p.202). And the latter, "the entity as a whole" is supposed to be the object of "metontology" (GA26, p.199, p.202). Now, these two tasks of Heidegger's metaphysics are not totally independent from each other, but they are just "the double concept of philosophy" (GA26, p.202), so that in the end it must be accounted how they could be integrated. To this question of possible integration of metaphysics, Heidegger seems to answer in WS1929/30, whereby he supposes the ability of Dasein which grasps "the entity as a whole" in its totality in advance. He maintains that "the pre-logical (vorlogisch) openness toward the entity out of which all logos must be spoken out always and already supplements and makes total (ergänzt) the entity into "as a whole". This totalizing supplement (Ergänzung) should be defined as the preceding formation (das vorgängige Bilden) of « as a whole » in its factic reigning. " (GA29/30, p.505). By this, "the world as the manifestation (Offenbarkeit) of the entity as such as a whole" and its "World-formation (Weltbildung)" are first possible (GA29/30, p.507). Our statement above could be justified by these passages.
} 
is nevertheless the idea in the early Heidegger ${ }^{8}$. This is the primal twosidedness constituting the event that "the entity as a whole" emerges. "The clearance" and "the concealment" should be understood in this way.

Then, how do we experience this twofoldness in the moment where we come into existence in it? The consequence from the above is that the emergence of the entity must be experienced as that which supports the existence of the entity, and that this support appears in the two-sided relationship to the entity. On one hand, since Dasein as the entity cannot comprehend what is not to determine from the entity, the emergence of the entity must be experienced only in relation to the entity in this emergence. However, on the other hand, the emergence cannot be determined from the entity. Therefore, as has just been stated, the emergence of the entity must be experienced both as what conceals itself from the entity and as what is somehow related to the entity.

Now, this experience of the support of existence should be concretely regarded as what appears to us in the manner that it is addressing us. Here is the reason the concrete experience of the clearance and the concealment is understood as the advent of the alterity. To see this, we just need to point out that Dasein has his own first-person point of view, when s/he experiences the support of her/his own existence. Otherwise put, in this experience, we, Dasein, are being forced to face what comes to support our existence in "the entity as a whole", so that all of our comportments could be regarded as the response to what is addressing us. Such reading can be justified by the passage in $C P$ as follows: "This suffering (of Seinsverlassenheit) must belong to the call (Zuruf) of the reign of the wink (of the last god)" (GA65, p.408, my supplement) ${ }^{9}$. Here, experience supporting one's own existence may not be confused with the objective duration of what has once come into existence. As Heidegger says that "the last god" "tears" and "destroys" "the net" of "the event (Ereignis)" and "its temporal space (Zeit-Raum) in "its singularity" while "the last god"

\footnotetext{
${ }^{8}$ See the exemplary passage from SS1927: "Being and its determinations found in a sense the entity and precede it, and are thus про́твроv and the earlier (ein Früheres)." (GA24, p.27) The self-critic against such position is clearly expressed in CP as follows: "Being is not "the earlier" which might hold for itself. Rather, the event is temporal -spatial (zeiträumlich) simultaneity (Gleichzeitigkeit) for Being and the entity" (GA65, p.13).

${ }^{9}$ The experience of the alterity is described also as suffering of regard. In SS1943 is stated as follows: "Heraklit here speaks of in what way Apollo is the one who acutely throws his look (der Hereinblickende) and appears, and how Apollo gives his wink into Being in his appearance. The god

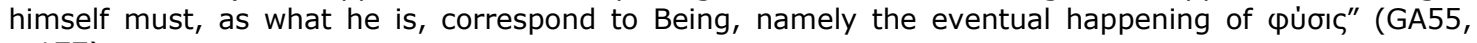
p.177).
} 
"hangs himself" on it (GA65, p.263), the advent of the alterity is experienced in the manner that the assumed identity of what has come to existence will be summoned and destroyed.

In summary, the reason the twofoldness of the clearance and the concealment involves the experience of the alterity is that the advent of what sustains the existence of "the entity as a whole" happens in the manner of addressing Dasein. And this is the experience of the alterity in the sense that it arrives to the entity in the mentioned two-sided manner and incessantly breaks the identity of the entity.

(2) Then, what could be the answer to the second question, how the alterity just considered and the entity coming into existence in the clearance and the concealment are related to each other? About this, we need to consider Heidegger's assumption that another kind of alterity described as a moment of "fourfold (Geviert)" be grounded by the alterity we have just investigated. In Poet for what sake? (1946), the following is stated:

The ether only in which the gods (Götter) could be the gods is their godliness (Gottheit). The element of this ether in which the godliness itself eventually emerges (west) is the sacred (das Heilige). The element of the ether for the arrival of escaping gods, namely, the sacred is the trace of the escaping gods." (GA5, p.272 my emphasis) ${ }^{10}$

Such description suggests the answer to our question. We have already maintained that the primal alterity involved in the twofoldness of Being has the two-sided relationship to the entity amid its emergence. Then, the above passage suggesting the priority of "the sacred" to "the gods" seems to say that "the gods" as a moment of "fourfold" signify the aspect of the entity in this twosidedness.

First, as has been emphasized, the primal alterity involved in the clearance and the concealment must be experienced in relation to the entity, although it cannot be assimilated in the entity. As to this point, Heidegger's own descrip-

\footnotetext{
${ }^{10}$ In Building, Living and Thinking (1951) is stated as follows: "The godlikes are the messenger giving winks into the deity (Gottheit). Out of the holy reign of the deity, the god appears into his presence, or retreats (sich entziehen) into his concealment (Verhüllung)." (GA7, p.151). The same is the case about the quoted passage in On the Beginning (See note 5). Further, also in $C P$, Heideggers speaks of "the winks of the last god as ourburst and defect of arrival and escape of the gods (die Winke des letzten Gottes als Anfall und Ausbleib der Ankunft und Flucht der Götter)" (GA65, p.408) and regards the twosidedness of "the last god" to be the ground of that of "the gods".
} 
tions show subtle inconsistency. On one hand, "the gods" are deprived of the determination of the entity with the statement that "the gods" do not "exist (sind)" at all (GA65, p.244). On the other hand, "the last god" is called "the most alien (das Fremdeste) of all entities" (GA65, p.263), and attributed an explicit relationship with the entity. However, such descriptive ambiguity is nothing but the reflection of the two-sidedness in the subject matter itself. The advent of the alterity is, on one hand, experienced only in relation to the entity.

From the consideration above, we could say that this ontic aspect of the primal alterity could be paraphrased as the origin of "the entity as a whole", the emergence of which Dasein is facing. Otherwise put, this ontic aspect of the alterity comes to us in the status of the entity and appears as what sustains the existence of "the entity as a whole". Such experience has much in common with what is called "divine" in daily language. Further, this is the subject matter taken up since the metaphysical period in the late 1920s, and the insight in the later writings after $C P$, which is shown in the continuity of the terminologies. As is well known, in the 1928 summer lecture, Heidegger exhibits his double project of metaphysics and calls the study of "the entity as a whole" "metontology (Metontologie)" (GA26, p.199). To this subject matter, Heidegger attributes "the understanding of being as overwhelming power (Übermächtiges), that is, as sacredness (Heiligkeit)" (GA26, p.211, n.3). In the following lecture WS1928/29, he further speaks of "sheltering (Bergung)" as one of the two fundamental attitudes to disclose Dasein's transcendence (GA27, p.366). Heidegger characterizes "sheltering" as "mythical Dasein", namely, as "being handed down to the overwhelming power" of "the entity as a whole" (GA27, p.358), which should constitute the foundation of various religious comportments like magic and ritual (GA27, p.359). Now, since the term "overwhelming power (Übermacht)" is also used in CP (GA65, p.415: "The god overwhelms human beings"), and the term "resisting support (Widerhalt)" (GA26, p.248) as the resisting character of "the world" in SS1928 is also used to describe "disunited dialog (Entgegnung)" between the gods and human beings in Meditation (GA66, p.83f.; Besinnung: 1938/39), we could conclude that the holiness of the 
ontic aspect in the emergence of "the entity as a whole" is further succeeded to the much later conception of the alterity in "fourfold" ${ }^{11}$.

\section{Alterity amid the Entity as a Whole: "The Godlikes" in "Fourfold"}

Our next task is to consider the just mentioned alterity and to focus on how this is experienced in its relationship to the entity. In other words, the question here is how "the godlikes (die Göttlichen)" or "the gods (die Götter)" as a component of "fourfold" are experienced. Heidegger's own explanation about this is surprisingly inadequate. However, his terminology, its definition and his examples provide the clue to the essential characteristics of the experience of "the godlikes".

First, Heidegger characterizes the encounter of "the godlikes" or "the gods" to human beings, that is, "the mortals (die Sterblichen)" as "disunited dialog (Entgegnung)". "Entgegnung" in daily German means response or objection. Since this term is equated with "the dialog (Gespräch)" in On the Essence of Language (since the late 1930s) (GA74, p.144), a kind of communication is also implied in Heidegger's usage. However, as is shown in his rejection of its characterization as an "I-thou" relationship (GA74, p.143), "Entgegnung" does not mean a vis-à-vis communication between human beings. Second, in Meditation (1938/39), Heidegger defines "disunited dialog" as "essentially decisive conflict (Wesensentscheidung) between the deity of the gods and the humanity of human beings" (GA66, p.84), which is suggestive for clarifying the meaning of the term. As Watanabe (2008) pointed out, the term "decisive conflict (Entscheidung)" signifies the movement of Being where the gods and human beings are situated in a mutual relationship $(2008 ; 328 \mathrm{ff})^{12}$. Since this conflict is also attributed to "the last god", it is experienced in the above mentioned two-sided relationship to human beings, which is shown by the expressions like "the most distant nearness" (GA65, p.27), "arrival and flight" (GA65, p.31; see GA5, p.272) or "appear (erscheinen)" and "retreat (entziehen)" (GA7, p.180).

\footnotetext{
${ }^{11}$ Here, we presuppose that "fourfold" describes how "the entity as a whole" emerges in the twofoldness of "the clearance" and "the concealment", which is for expmale shown by the passage in The History of Being (1939/40) as follows: "Earth is the eventual emergence (Wesung) of the entity as a whole. World is the eventual emergence of the entity as a whole. Earth and world belong the being of the entity as a whole." (GA69, p.19).

${ }_{12}$ Watanabe, Jiro, Research Notes for Heidegger's Second Main Writing «Contributions to Philosophy », Riso-sha, Tokyo, 2008 (Japanese)
} 
Then, it would be self-evident that the communication of such two-sidedness must be distinguished from the daily dialog between living humans. As we will see in the following, Heidegger actually calls the human response to the alterity "sacrifice (Opfer)" and, in Thing (1950), counts the donation of drink to the gods as an example of it (GA7, p.174). This shows that asymmetric communication like sacrifice or donation is regarded as the model for the experience of "the godlikes". In sum, the experience of "the godlikes" should be characterized as what arrives to the entity in a two-sided manner, appearing and retreating, and thus involves human beings in a primordially asymmetric communicative relationship (See GA74, p.143).

Of course, such determination tells little. Moreover, to the best of my knowledge, there is no textual proof in the later Heidegger to further specify the subject matter. Then, we would like to use and modify the more articulated concepts in $B T$, so that further investigation would be possible. As to this, we would like to maintain that the experience of "the godlikes" should be formulated as "asymmetry of "articulating communication (Mitteilung)".

In $B T$, those who address us are the other beings given the existential determination of "Mitdasein". The communication between them and me is called "Miteinandersein". However, "Miteinandersein" itself is a mere formal category for communication in general and contains no concrete content. Rather, what specifically determines our communication with the other is "discourse (Rede)" as "the articulation of possibility of understanding" (SZ, p.161), especially, "articulating communication" as the public aspect of "discourse". "Articulating communication" determines the mood and the understanding in the mutual relation between Dasein and the other, as it is defined as "articulation of understanding Miteinandersein" which "articulates (teilt) the possibility of understanding in a communal state of being (Befindlichkeit) and Mitsein" (SZ, p.162). This communal order contains a wide range of communicative relations from the mood to the language. However, although to a certain extent the experience of "addressing us" would be acknowledged here, the theory of BT cannot explain the asymmetric dialog with "the godlikes". It is because Dasein in BT can only understand an ontologically symmetric mutual relation, the emergence of which is founded upon singular Dasein, insofar as Dasein cannot understand what has been experienced preceding the ecstatic unity of "Zeitlichkeit" (SZ, p.349). Otherwise put, in $B T$, in each moment (jeweilig) the others are address- 
ing in a certain articulated way, the existence of Dasein responding according to this articulation is already and always presupposed, the structure which could be formalized as follows: The addressing comportment $A$ of the other structurally implies the responding comportment B of Dasein, and B further structurally implies the responding comportment $C$ of the other and so on.

Now, to properly determine an asymmetric relationship with "the godlikes" above mentioned, we need to modify this symmetry of "articulating communication" in "Miteinandersein" on two points. First, the responding comportment of Dasein no longer structurally implies the addressing or responding comportment preceding or following Dasein's response. Second, what is addressing is no longer confined to the entity with the same ontological status as Dasein, but expanded to "the entity as a whole". The first modification provides the form of the experience of primal asymmetry where we are forced to respond without calculating the preceding or following comportment of the other. Just as "articulating communication" in BT contains various levels from mood to language, this experience of asymmetric communication could be further categorized into many types ${ }^{13}$. The second modification, which I think is a necessary consequence of Heidegger's philosophy after the metaphysical period, enables accounting for the non-human entity addressing us, namely "the godlikes". Further, though the later Heidegger seems to cling to Christian understanding of holiness, which rejects nature-worship, we theoretically need to acknowledge natural objects like stone or woods, and artificial things like the relics of a holy person as the instance for "the godlikes", because "the entity as a whole" is not necessarily confined to the divinity with personality.

\section{Repetition of Alterity: "SACRifice" as "Preservation" of Divinity}

Now, what could be human comportment that would properly disclose and respond to this experience of the alterity? Otherwise put, what is it like to dis-

\footnotetext{
${ }^{13}$ For example, the mood of holiness surrounding religious buildings or great stone and woods could be counted as the instance of such asymmetry on the level of "state of being". Further, religious symbols like the cross or statute are the experience of asymmetry on the level of sign. Finally, the religious laws or teachings written in the bible of the other religious writings would be the instance on the level of language.
} 
close the experience of the alterity amid the twofoldness of the clearance and the concealment? ${ }^{14}$

The central answer of Heidegger to this question is "sacrifice (Opfer)". As is well known, in The Origin of Artwork (1936), "sacrifice" is counted as "a way the truth eventually emerges (west)" besides art, "grounding of state" or "thinking" (GA5, p.49). Since, in CP, "sacrifice" is supposed to "prepare" "the dawning of a possible wink of the last god" (GA65, p.411) and, in The Thing, the human comportment to "the gods" is sought in "sacrifice" of drink, it is obvious, that "sacrifice" is regarded as the model of human response to the alterity. Then, we need to clarify (1) why "the preservation" of the truth of Being is characterized as "sacrifice" with regard to "the last god" and "the godlikes", and (2) the kinds of types we distinguish about this "sacrifice", which must have various faces according to the context of our experience.

(1) To answer the first question, we need to clarify the general meaning of "preservation" and then specify its narrower meaning with regard to "the last god" and "the godlikes". As was stated above, after giving up the thought of "transcendence", the later Heidegger seeks to disclose the emergence of "the entity as a whole" amid the entity and to appropriate it in human communication with the entity. "Preservation (Bergung)" is nothing but the name of this repetition of the truth: "The grounding (Ergründung) of the event takes place rather as the preservation of truth in the entity and as the entity" (GA65, p.322). The same action is also called "grounding (Gründung)" (See GA65, p.247) and variously categorized into "art", "thinking", "poetry" or "action" (GA65, p.256) ${ }^{15}$. Then, what does it mean to "preserve" the truth of Being "in the entity and as the entity"? The point about this is that the object of the human comportment here is of the twofoldness of the clearance and the concealment. On one hand, due to the character of the concealment, it is not at all possible to make present the truth of Being defined as the emergence of "the entity as a whole". We can only comport ourselves to the entity. On the other hand, due to the character of the clearance, our comportment to the entity it-

\footnotetext{
${ }^{14}$ Heidegger expresses this as follows: "In the wink (of the last god), Being, i.e. the event itself is first visible. And this brightness needs the grounding of eventual emergence of the truth as the clearance and the concealment, and its final preservation (Bergung) in modified figures of the entity." (GA65, S.70 my supplement)

15 "The truth (of the event), i.e. the truth itself eventually emerges only in the preservation as art, thinking, poetry and action" (emphasis by Heidegger, my supplement)
} 
self always embodies the emergence of "the entity as a whole", whether or not we know this. From this, the task of "preservation" could be paraphrased as the explicit repetition of our comportment to the entity as such comportment, which is involved in the twofoldness of the clearance and the concealment (see, GA65, p.30).

Then, what is it like to "preserve" the experience of the alterity? The determination of the experience of the alterity acquired above is that Dasein is forced to respond to addressing or responding comportment that is not implied in Dasein's own response. Therefore, the preservation of the alterity must be understood as the explicit repetition of such asymmetric communication, which implies that one has to "prepare (vorbereiten)" the arrival and to "retrospect (andenken)" the bygone trace of such experience ${ }^{16}$. Now, such "preservation" should be characterized as leaving and entrusting the entities in our possession such as meals, wealth, thought, body, life or the totality of our world, to what is inevitably coming to us. It is because we must situate ourselves in such a communicative situation where we give up our control over the entity belonging to us. Then, it would be natural to call such "preservation" "sacrifice", if we understand it in a broad sense including many actions such as devotion.

(2) This consequence answers the second question. Asymmetry of "articulating communication" shows various grades in each context of experience. Therefore, "the preservation" of such experience must also vary in each context. On one hand, in $C P$, "the sacrifice" is called "the choice of the shortest and hardest orbit (Bahn)" (GA65, p.408). Since, in the later Heidegger, "orbit" means providence of historical world ${ }^{17}$, "the sacrifice" here is supposed to sacrifice "the entity as a whole" where we are also living. On the other hand, in The Thing, serving the drink is also regarded as "the sacrifice" for "the immortal gods" (GA7, p.174), whereby only a small part of our possession is dedicated to the alterity.

\footnotetext{
${ }^{16}$ Famously, Heidegger regards the thinking of Being to be temporally extended to the future and the past. This is also the case with the experience of the alterity. In CP, "sacrifice" is supposed to "prepare (vorbereiten)" "the wink of the last god" (GA65, p.410f.). And in The Event (1941/42), "the last god" is regarded to be "the highest god of the first beginning (erstanfänglich)" and "all the bygone (alle Gewesenen) eventually emerge with him", which suggests that the comportment to the divinity is also oriented towards the past.

${ }^{17}$ See The Origin of Artwork: "The world is the self-opening openness of the orbit for the simple and essential decision in the destiny of historical fork" (GA5, p.35)
} 


\section{CONCLUDING REMARKS}

The results of this paper could be summarized as follows. First, the concrete experience of the twofold of "the clearance" and "the concealment" involves the advent of the primal alterity called "the last god" and "the sacred". That is, in every moment of the event where "the entity as a whole" emerges, we experience and face what addresses us and sustain our existence. Second, "the godlikes" are the ontic aspect of such alterity, which has a two-sided relationship to the entity. Third, authentic disclosure of such experience called "sacrifice" is to leave and entrust the entity of our possession to the alterity.

With these consequences, however, we have considered only the aspect of the alterity and the human response to it, which are clearly important but just a part of the eventual emergence of the entity. Simply put, Heidegger's concept of "fourfold" further provides us with possibilities to consider history/natural history, nature and human beings, on which investigation of the subject matters and their "preservation" is required. On the ground of these tasks, the first requirement is to study mutual relations between the moments of "fourfold" in the phenomenologically justified manner. Then, it is subsequently demanded to consider relations between the various types of "the preservation", which will give us the integrative understanding of the varieties of human action responding to the emergence of the event. With this, we could approach the universal understanding of the subject matter "phenomenon", while irreducible varieties of each experience are also considered. This would help us to see how we are primordially rooted in the factic multiplicity of our lives and related with each other, which must be the final instance for considering how reason is possible in our lives. 